\title{
STUDIES OF SERUM CREATINE TOLERANCE. I. FINDINGS IN NORMAL MALES AND IN HYPERTHYROIDISM ${ }^{1,2}$
}

\author{
BY JOHN H. PETERS, ROBERT SCHWARTZ, HOWARD MERMELSTEIN, MERCINE \\ N. NEFORES, AND MATTHEW M. MANSUY
}

(From the Department of Research Medicine and the Renziehausen Foundation of the University of Pittsburgh School of Medicine, the Presbyterian Hospital, and the United States Veterans Hospital, Aspinwall, Pennsylvania)

(Submitted for publication March 3, 1951; accepted May 23, 1951)

In 1929, Palmer, Carson, and Sloan (1) reported that treatment of exophthalmic goiter with Lugol's solution reduced or abolished the associated creatinuria. More recently Richardson and Shorr $(2,3)$ and Thorn (4) have shown that hyperthyroid individuals excrete a larger proportion of a given dose of creatine than do comparable normal individuals, and that this "reduced tolerance" is partially or totally reversible by effective therapy. The development by one of us of a practical method for the determination of creatine in serum (5) led Tierney and J. P. Peters to investigate the effects of exogenous creatine on serum levels in normal humans and in thyroid disease (6). Their findings revealed that the increased creatinuria reflected increased serum concentrations, and that the "critical" serum level for the excretion of creatine was approximately $0.6 \mathrm{mg}$. \%.

Because of the differences in the mode of excretion of creatine by adult males and females, we have undertaken a study of serum creatine tolerances of men with hyperthyroidism and of others with clinical conditions simulating Graves' disease in order to further define the nature of sex differences in creatine metabolism. It also seemed important to determine whether the increased tolerance noted by Tierney and Peters in one male (6) was a characteristic of this disease in men.

\section{MATERIALS AND METHODS}

Thirteen "normal" subjects were selected from laboratory personnel, faculty members and resident physicians

1 This investigation was supported in part by a research grant from the National Institutes of Health, Public Health Service.

2 Sponsored by the Veterans Administration and published with the approval of the Chief Medical Director. The statements and conclusions published by the authors are a result of their own study and do not necessarily reflect the opinion or policy of the Veterans Administration.
(Table I). Patients, most of whom were hospitalized, were selected in whom the diagnosis of hyperthyroidism was established or suspected. In addition, certain individuals who had non-toxic thyroid enlargement were tested. Ultimate diagnosis in each case was based on clinical observations, determination of serum precipitable iodine prior to therapy, and single or serial measurements of basal metabolic rate and serum cholesterol (Tables II and III). In most instances, serum protein and albumin were also determined in order to rule out hypoalbuminemia as a possible cause of confusion in the interpretation of serum iodine data (7), and in two patients,

TABLE I

Normal subjects

\begin{tabular}{l|c|c|c|c}
\hline \hline Patient & Sex & Age & Date* & $\begin{array}{c}\text { Serum } \\
\text { iodine } \\
\gamma \%\end{array}$ \\
\hline W. B. & M & 27 & $8 / 30 / 50$ & \\
K. G. & M & 27 & $8 / 31 / 50$ & 5.4 \\
G. R. & M & 28 & $9 / 1 / 50$ & \\
F. M. & M & 29 & $9 / 15 / 50$ & 5.5 \\
L. N. & M & 21 & $10 / 23 / 50$ & 5.7 \\
G. H. & M & 25 & $11 / 8 / 50$ & 4.7 \\
C. C. & M & 29 & $11 / 16 / 50$ & \\
M. S. & M & 30 & $11 / 7 / 50$ & \\
M. L. & F & 22 & $11 / 14 / 50$ & 5.3 \\
P. L. & F & 22 & $1 / 18 / 51$ & 3.9 \\
D. B. & F & 26 & $1 / 22 / 51$ & \\
E. C. & F & 23 & $1 / 23 / 51$ & 7.3 \\
M. W. & F & 27 & $1 / 23 / 51$ & 5.5 \\
\hline
\end{tabular}

* Refers to dates of creatine tolerances illustrated in Figure 1. Serum iodine was determined prior to tolerances in most instances.

serum "thyroxine" concentration (8) was also measured to verify the functional significance of artifactually elevated iodine values (9). The euthyroid state of a majority of the normal subjects had been verified by determination of serum precipitable iodine (8) in the course of other investigations of thyroid function (10).

Creatine tolerance tests were performed prior to therapy, ten days after the start of therapy, preoperatively and postoperatively whenever possible. The hospital patients were kept at bed rest during the tolerance periods, but the normal subjects and outpatients were permitted to indulge in limited ambulatory activity in the laboratory. The procedure followed was that of Tierney and Peters (6) with the following exceptions: (a) the inter- 
vals for collection of specimens were varied for reasons discussed under Results below, $(b)$ urine collections were omitted, since other data have demonstrated that in the absence of renal disease, the presence or absence of cre- atinuria is governed by serum creatine concentration ( 6 , $11,12)$, and $(c)$ autoclaving of specimens for the analysis of total creatinine was carried out in $12 \mathrm{ml}$. volumetric flasks rather than in colorimeter tubes so that any evapora-

TABLE II

Thyrotoxicosis-clinical data

\begin{tabular}{|c|c|c|c|c|c|c|c|c|c|c|c|c|c|}
\hline \multirow{2}{*}{$\begin{array}{c}\text { Patient } \\
\text { Age } \\
\text { No. }\end{array}$} & \multirow[b]{2}{*}{ Date* } & \multirow[b]{2}{*}{$\begin{array}{c}\text { Figure } \\
\text { ref. }\end{array}$} & \multirow[b]{2}{*}{$\begin{array}{l}\text { Wt. } \\
\left(K_{g_{.}}\right)\end{array}$} & \multirow[b]{2}{*}{$\begin{array}{c}\text { Pulse } \\
(/ m i n .)\end{array}$} & \multirow[b]{2}{*}{$\begin{array}{c}\text { BMR } \\
(\%)\end{array}$} & \multicolumn{3}{|c|}{ Serum } & \multicolumn{4}{|c|}{ Therapy } & \multirow[b]{2}{*}{ Clinical } \\
\hline & & & & & & $\begin{array}{l}\text { Chol. } \\
\text { (mg. \%) }\end{array}$ & $\mid \begin{array}{l}\text { Iodine } \\
(\gamma \%)\end{array}$ & $\left|\begin{array}{c}\text { Albumin } \\
(\mathrm{gm} . \%)\end{array}\right|$ & $\begin{array}{c}\text { Date } \\
\text { started }\end{array}$ & $\begin{array}{c}\begin{array}{c}\text { Lugol's } \\
(\text { drops } \\
/ d)\end{array} \\
\end{array}$ & $\begin{array}{l}\text { Propyl } \\
\text { thiour. } \\
\text { (mg./d.) }\end{array}$ & $\begin{array}{c}\text { Opera- } \\
\text { tion } \\
\text { date }\end{array}$ & \\
\hline $\begin{array}{l}\text { J. S. } \\
\text { No. } 72609 \\
\text { No. }\end{array}$ & $\begin{array}{l}8 / 22 / 49 \\
9 / 6 / 49\end{array}$ & $\begin{array}{l}2 \mathrm{~A} \\
\mathbf{3 A}\end{array}$ & \begin{tabular}{|l|}
60.1 \\
62.8
\end{tabular} & $\begin{array}{l}76 \\
76\end{array}$ & $\begin{array}{l}+74 \\
+12\end{array}$ & 174 & 13.1 & & $8 / 26$ & 30 & 300 & & $\begin{array}{l}\text { Rheum. ht. disease, fibrilla- } \\
\text { tion, failure. Large thy- } \\
\text { roid, clinically toxic. Left } \\
\text { hospital against advice. }\end{array}$ \\
\hline \multirow{2}{*}{$\begin{array}{l}\text { H. N. } \\
30 \\
\text { No. } 78051\end{array}$} & \multirow{2}{*}{$\begin{array}{r}8 / 26 / 49 \\
9 / 13 / 49 \\
10 / 3 / 49 \\
3 / 16 / 50\end{array}$} & \multirow{2}{*}{$\begin{array}{l}2 \mathrm{~A} \\
3 \mathrm{~A} \\
4 \mathrm{~A} \\
4 \mathrm{~B}\end{array}$} & \multirow{2}{*}{$\begin{array}{l}70.1 \\
70.5 \\
72.8 \\
78.7\end{array}$} & \multirow{2}{*}{$\begin{array}{l}90 \\
88 \\
88 \\
80\end{array}$} & \multirow{2}{*}{$\begin{array}{l}+85 \\
+16 \\
+29\end{array}$} & \multirow[t]{2}{*}{171} & \multirow[t]{2}{*}{12.3} & \multirow[b]{2}{*}{5.2} & \multirow[t]{2}{*}{$9 / 1$} & \multirow{2}{*}{$\begin{array}{l}30 \\
30\end{array}$} & \multirow{2}{*}{$\begin{array}{l}300 \\
300\end{array}$} & & \multirow{2}{*}{$\begin{array}{l}\text { Clinical opinion divided. } \\
\text { Majority for thyrotoxicosis. } \\
\text { Path:diffuse colloid involu- } \\
\text { tion. }\end{array}$} \\
\hline & & & & & & & & & & & & $11 / 25$ & \\
\hline $\begin{array}{l}\text { A.S. } \\
29 \\
\text { No. } 79501\end{array}$ & $\begin{array}{r}11 / 2 / 49 \\
11 / 17 / 49 \\
12 / 5 / 49 \\
4 / 27 / 50 \\
\end{array}$ & $\begin{array}{l}2 \mathrm{~A} \\
3 \mathrm{~A} \\
4 \mathrm{~A} \\
\mathbf{4 B} \\
\end{array}$ & $\begin{array}{l}64.6 \\
68.7 \\
75.5\end{array}$ & $\begin{array}{r}120 \\
120 \\
108 \\
90 \\
\end{array}$ & $\begin{array}{r}+49 \\
+44 \\
+24 \\
+9 \\
\end{array}$ & $\begin{array}{l}121 \\
245\end{array}$ & 18.3 & 5.1 & $\begin{array}{l}11 / 3 \\
11 / 14 \\
12 / 3\end{array}$ & 30 & $\begin{array}{l}450 \\
300 \\
450\end{array}$ & $1 / 27$ & Clinically classic. \\
\hline $\begin{array}{l}\text { B. J. } \\
62 \\
\text { No. } 76206\end{array}$ & $\begin{array}{l}1 / 10 / 50 \\
2 / 7 / 50 \\
2 / 27 / 50 \\
4 / 25 / 50\end{array}$ & $\begin{array}{l}2 \mathrm{~A} \\
3 \mathrm{~A} \\
4 \mathrm{~A} \\
4 \mathrm{~B}\end{array}$ & $\begin{array}{l}72.3 \\
71.9 \\
72.8 \\
74.6\end{array}$ & $\begin{array}{l}90 \\
92 \\
80\end{array}$ & $\begin{array}{l}+34 \\
+42 \\
+40 \\
+7\end{array}$ & 222 & $25.3 t$ & & $1 / 25$ & & $\begin{array}{l}300 \\
300\end{array}$ & $4 / 14$ & $\begin{array}{l}\text { Toxicity questioned clinically. } \\
\text { Had been on Lugol's gtts. } \\
\text { xv/d. for } 4 \text { mos. prior to } \\
\text { to } 1 / 1 / 50 . \\
\text { Path:colloid adenoma and } \\
\text { chronic thyroiditis; local. } \\
\end{array}$ \\
\hline $\begin{array}{l}\text { R. R. } \\
26 \\
\text { No. } 80185\end{array}$ & $\begin{array}{l}1 / 20 / 50 \\
2 / 3 / 50 \\
2 / 21 / 50 \\
5 / 3 / 50\end{array}$ & $\begin{array}{l}2 \mathrm{~A} \\
3 \mathrm{~A} \\
4 \mathrm{~A} \\
4 \mathrm{~B}\end{array}$ & $\begin{array}{l}59.6 \\
62.3 \\
73.3\end{array}$ & $\begin{array}{r}116 \\
96 \\
110 \\
88\end{array}$ & $\begin{array}{r}+53 \\
+60 \\
+34 \\
+4\end{array}$ & $\begin{array}{l}121 \\
295\end{array}$ & 22.8 & 5.7 & $\begin{array}{l}1 / 21 \\
2 / 23\end{array}$ & & $\begin{array}{l}400 \\
600\end{array}$ & $4 / 20$ & $\begin{array}{l}\text { Clinically classic. } \\
\text { Path: hyperplasia with involu- } \\
\text { tion. }\end{array}$ \\
\hline $\begin{array}{l}\text { F. B. } \\
24 \\
\text { No. } 76606\end{array}$ & $\begin{array}{l}1 / 31 / 50 \\
2 / 10 / 50 \\
3 / 2 / 50 \\
3 / 17 / 50 \\
\end{array}$ & $\begin{array}{l}2 \mathrm{~A} \\
3 \mathrm{~A} \\
4 \mathrm{~A} \\
4 \mathrm{~B} \\
\end{array}$ & $\begin{array}{l}54.1 \\
56.9 \\
63.7 \\
64.2 \\
\end{array}$ & $\begin{array}{l}84 \\
80 \\
\end{array}$ & $\begin{array}{r}+80 \\
+68 \\
+24 \\
+9 \\
\end{array}$ & 145 & 11.2 & 5.1 & $\begin{array}{l}1 / 31 \\
2 / 16\end{array}$ & 15 & $\begin{array}{l}300 \\
300\end{array}$ & $3 / 8$ & Clinically classic. \\
\hline $\begin{array}{l}\text { F. G. } \\
54 \\
\text { No. } 82795\end{array}$ & $\begin{array}{l}4 / 3 / 50 \\
4 / 24 / 50 \\
5 / 17 / 50\end{array}$ & $\begin{array}{l}2 A \\
3 A \\
4 B\end{array}$ & $\begin{array}{l}62.2 \\
63.1 \\
64.0\end{array}$ & $\begin{array}{l}92 \\
84 \\
80\end{array}$ & $\begin{array}{l}+32 \\
-4\end{array}$ & $\begin{array}{l}178 \\
208\end{array}$ & 10.4 & 3.9 & $4 / 11$ & 15 & & $5 / 10$ & $\begin{array}{l}\text { Clinically doubtful. } \\
\text { Path:colloid and fetal adeno- } \\
\text { mata. }\end{array}$ \\
\hline $\begin{array}{l}\text { S. M. } \\
57 \\
\text { No. } 77983\end{array}$ & $4 / 7 / 50$ & $2 \mathrm{~A}$ & 60.4 & 72 & -4 & 269 & 8.6 & 4.5 & & & & $5 / 3$ & $\begin{array}{l}\text { Clinically non-toxic adenoma. } \\
\text { No preoperative therapy. } \\
\text { Path:multiple colloid adeno- } \\
\text { mata. }\end{array}$ \\
\hline $\begin{array}{l}\text { C. B. } \\
23 \\
\text { No. } 78465 \\
\end{array}$ & $4 / 14 / 50$ & $2 \mathrm{~A}$ & 68.2 & 100 & +32 & 208 & 12.1 & 4.5 & . & & & & $\begin{array}{l}\text { Clinically classic-left } \\
\text { pital without therapy. }\end{array}$ \\
\hline $\begin{array}{l}\text { L. McM. } \\
55 \\
\text { No. } 78493\end{array}$ & $\begin{array}{l}5 / 25 / 50 \\
6 / 9 / 50 \\
6 / 29 / 50\end{array}$ & $\begin{array}{l}2 \mathrm{~A} \\
3 \mathrm{~A} \\
\mathbf{4 A}\end{array}$ & $\begin{array}{l}43.6 \\
44.0 \\
44.9\end{array}$ & $\begin{array}{l}80 \\
76 \\
80\end{array}$ & $\begin{array}{l}+26 \\
+12 \\
-1\end{array}$ & $\begin{array}{l}160 \\
296\end{array}$ & 16.1 & 4.5 & $\begin{array}{l}5 / 29 \\
5 / 31 \\
6 / 12\end{array}$ & & $\begin{array}{l}200 \\
300 \\
200\end{array}$ & & $\begin{array}{l}\text { Classic " apathetic" thyro- } \\
\text { toxicosis. Not operated. } \\
\text { X-ray: decreased cardiac } \\
\text { shadow on treatment. }\end{array}$ \\
\hline $\begin{array}{l}\text { W. G. } \\
27 \\
\text { No. } 80842\end{array}$ & $\begin{array}{l}7 / 17 / 50 \\
7 / 28 / 50 \\
8 / 18 / 50 \\
9 / 13 / 50 \\
\end{array}$ & $\begin{array}{l}2 \mathrm{~A} \\
3 \mathrm{~A} \\
4 \mathrm{~A} \\
4 \mathrm{~B} \\
\end{array}$ & $\begin{array}{l}49.5 \\
53.6 \\
55.8 \\
59.0 \\
\end{array}$ & $\begin{array}{r}100 \\
100 \\
96 \\
76 \\
\end{array}$ & $\begin{array}{r}+58 \\
+37 \\
+12 \\
+4 \\
\end{array}$ & 186 & 17.9 & 4.6 & $\begin{array}{l}7 / 17 \\
8 / 20\end{array}$ & & $\begin{array}{l}300 \\
400\end{array}$ & $9 / 6$ & Clinically classic. \\
\hline $\begin{array}{l}\text { A. T. } \\
29 \\
\text { No. } 80940\end{array}$ & \begin{tabular}{|c|}
$7 / 17 / 50$ \\
$7 / 31 / 50$ \\
$8 / 21 / 50$ \\
$9 / 20 / 50$ \\
$10 / 18 / 50$
\end{tabular} & $\begin{array}{l}2 \mathrm{~A} \\
3 \mathrm{~A} \\
4 \mathrm{~A} \\
4 \mathrm{~A} \\
4 \mathrm{~B}\end{array}$ & $\begin{array}{l}64.9 \\
66.7 \\
74.0 \\
75.1\end{array}$ & $\begin{array}{r}112 \\
100 \\
90 \\
80 \\
76\end{array}$ & $\begin{array}{r}+49 \\
+9 \\
+44 \\
+16 \\
+9\end{array}$ & 315 & 16.2 & 4.6 & $7 / 21$ & & $\begin{array}{l}300 \\
300 \\
300\end{array}$ & $1 / 10$ & $\begin{array}{l}\text { Thyroidectomy for thyro- } \\
\text { toxicosis } 10 \text { months previ- } \\
\text { ously. On small dosage of } \\
\text { propyl thiouracil for } 6 \text { mos. } \\
\text { prior to admission because } \\
\text { of recurrence. Clinically } \\
\text { classic. }\end{array}$ \\
\hline $\begin{array}{l}\text { J.H. } \\
\text { 44. A2906 } \\
\text { No. A2906 }\end{array}$ & $\begin{array}{r}9 / 26 / 50 \\
11 / 7 / 50\end{array}$ & $\begin{array}{l}2 \mathrm{~A} \\
4 \mathrm{~A}\end{array}$ & $\begin{array}{l}47.3 \\
56.0\end{array}$ & $\begin{array}{l}88 \\
83\end{array}$ & $\begin{array}{l}+63 \\
+16\end{array}$ & 211 & 18.4 & & $10 / 25$ & 30 & 300 & & $\begin{array}{l}\text { Clinically classic with exoph- } \\
\text { thalmos. } \\
\text { tion. }\end{array}$ \\
\hline $\begin{array}{l}\text { E. M. } \\
54 \\
\text { No. A3095 }\end{array}$ & $10 / 17 / 50$ & $2 \mathrm{~A}$ & 51.4 & 84 & +36 & 200 & 14.1 & 4.0 & & & & & $\begin{array}{l}\text { Classic with exophthalmos } \\
\text { and heart disease. Previous } \\
\text { operation. }\end{array}$ \\
\hline
\end{tabular}

* Date on which creatine tolerance was performed. In most instances other data obtained within $\pm 72 \mathrm{hrs}$. Serum for iodines drawn same day as tolerances.

$\dagger$ Previously on Lugol's solution. Serum thyroxine $10.05 \gamma \%$. 
tion losses in autoclaving could be made up quantitatively with distilled water prior to transfer for colorimetry. The increased creatinuria usually attributed to omission of a preliminary period of "creatine-free" diet is not sufficient to significantly affect the results of these studies (11, 13). Throughout this paper, the convention of reporting creatine values in terms of creatinine is followed.

\section{RESULTS}

\section{Normal tolerance curves}

Serum tolerances of eight young men (Table I) plus the two curves reported by Tierney and Peters (6) ${ }^{3}$ are presented in Figure 1A. It is readily apparent that reducing the number of determinations to three and reducing the duration of the test from 180 to 135 minutes gives essentially the same spread of values as the four-point (fasting, 30, 60, and 180 minutes) routine previously employed (6). That this is, for practical purposes, also true in abnormal curves will be clear from the data which follow. The data represented in Figure 1B strongly suggest that this modification is also applicable in normal females. The noteworthy characteristics of the normal male curve are: (a) fasting levels at or below $0.6 \mathrm{mg} . \%$, the level which approximates the minimum serum level associated with creatinuria, $(b)$ a definite rise at the inter-

${ }^{3}$ With the permission of the authors and publishers, data from their paper have been used in Figures 1-3 in order that our curves may readily be compared with similar findings in females. mediate ( 30 to 60 minutes) interval with considererable variation in degree of this rise, and $(c)$ a return at 135 or 180 minutes to serum concentrations of $1 \mathrm{mg} . \%$ or less. These details contrast with the normal females in whom fasting concentrations frequently exceed $0.6 \mathrm{mg} . \%$, and whose final values are usually in excess of $1.00 \mathrm{mg}$. \% (Figure 1B).

\section{Untreated hyperthyroidism}

In Figure 2A, it is apparent that the curves in these patients are quite different from the normal male group. Of the 14 cases represented only one value falls below the upper limit of the normal range at 135 minutes. Thus, the alterations seen in this group are similar to those previously reported in females ([6] and Figure 2B), although none reach the high concentrations seen in patient S. H. at 30 and 60 minutes. Laboratory and clinical data are summarized in Table II. In patients B. J. and F. G., the tolerance pattern confirmed other laboratory findings, particularly the iodine values, although originally clinical opinion was divided and final diagnostic decision had to be based on response to therapy. The curve which falls to the normal range represents a case in whom clinical opinion was also divided, despite a serum precipitable iodine concentration of $12.3 \gamma \%(\mathrm{H}$. N.-Table II). Again, the ultimate diagnosis of hyperthyroidism was based on therapeutic re-

TABLE III

Miscellaneous conditions

\begin{tabular}{|c|c|c|c|c|c|c|c|c|c|c|}
\hline \multirow{2}{*}{ Pt. } & \multirow{2}{*}{ Age } & \multirow{2}{*}{ No. } & \multirow{2}{*}{ Date } & \multirow{2}{*}{ Pulse } & \multirow{2}{*}{$\underset{(\%)}{\text { BMR }}$} & \multicolumn{3}{|c|}{ Serum } & \multirow{2}{*}{$\begin{array}{l}\text { Opera- } \\
\text { tion } \\
\text { date }\end{array}$} & \multirow{2}{*}{ Clinical } \\
\hline & & & & & & (mg. \%) & $\begin{array}{l}\text { Iodine } \\
(\gamma \% \%)\end{array}$ & $\begin{array}{c}\text { Albumin } \\
(\mathrm{gm} . \%)\end{array}$ & & \\
\hline H. W. & 25 & 77070 & $2 / 23 / 50$ & 78 & +9 & 261 & 5.3 & 5.4 & & Clinically thyroiditis or non-toxic ade- \\
\hline H. C. & 54 & 72479 & $\begin{array}{r}9 / 9 / 49 \\
10 / 4 / 49\end{array}$ & $\begin{array}{l}108 \\
100\end{array}$ & $\begin{array}{l}+42 \\
+31\end{array}$ & 228 & $55.2^{*}$ & 5.0 & & $\begin{array}{l}\text { Exoph thalmos. Clinically questionable. } \\
\text { Died of sarcoma. Path: normal thy- }\end{array}$ \\
\hline $\begin{array}{l}\text { E. L. } \\
\text { J. C. }\end{array}$ & $\begin{array}{l}48 \\
59\end{array}$ & $\begin{array}{l}71927 \\
78362\end{array}$ & $\begin{array}{l}8 / 25 / 49 \\
5 / 5 / 50 \\
6 / 9 / 50\end{array}$ & $\begin{array}{l}76 \\
90 \\
80\end{array}$ & $\begin{array}{r}-9 \\
+7\end{array}$ & $\begin{array}{l}231 \\
228\end{array}$ & $\begin{array}{l}3.8 \\
7.5\end{array}$ & & $6 / 2$ & $\begin{array}{l}\text { Non-toxic adenoma. } \\
\text { Non-toxic nodular goiter. } \\
\text { Path: fetal adenomas and colloid ade- }\end{array}$ \\
\hline E. D. & 38 & 78980 & $5 / 4 / 50$ & 75 & -6 & 333 & 4.4 & & $5 / 8$ & Non-toxic adenoma. Path: colloid ade- \\
\hline C. D. & 72 & 75487 & $\mid \begin{array}{r}12 / 29 / 49 \\
1 / 25 / 50 \\
2 / 15 / 50 \\
10 / 7 / 50\end{array}$ & $\begin{array}{l}60 \\
84\end{array}$ & $\begin{array}{l}+18 \\
+4 \\
+4 \\
-3\end{array}$ & $\begin{array}{l}145 \\
163 \\
268\end{array}$ & $\begin{array}{l}8.9 \dagger \\
7.17 \\
5.1\end{array}$ & 4.6 & & $\begin{array}{l}\text { Thyroidectomy } 1938 \text {. Cardiac failure. } \\
\text { On propyl thiouracil } 12 / 31-2 / 13 \text {. } \\
\text { No clinical response to medication. } \\
\text { Wt. loss, nervousness, sweating. }\end{array}$ \\
\hline
\end{tabular}

* Artifact due to "Priodax" cholecystography.

$\dagger$ Result questionable-? previous iodine therapy.

$\ddagger$ Thyroxine $-3.9 \gamma \%$. 
sponse. Patient S. M. was inadequately studied in that, unfortunately, complete follow-up was impossible. Thus although the creatine tolerance curve and serum iodine values were in the hyperthyroid range, all other evidence pointed to a nontoxic adenoma, and the patient was treated accordingly. However, on a postoperative visit in January, 1951 the patient was found to have gained ten pounds. If S. M. is considered to have been euthyroid, 12 of the 14 tolerances were in accord with the final diagnosis, one was falsely normal, and one was falsely hyperthyroid (H. N. and S. M., respectively). None of the curves in this series are of the flat type shown by the one hyperthyroid male previously reported ([6] and Figure 2A).

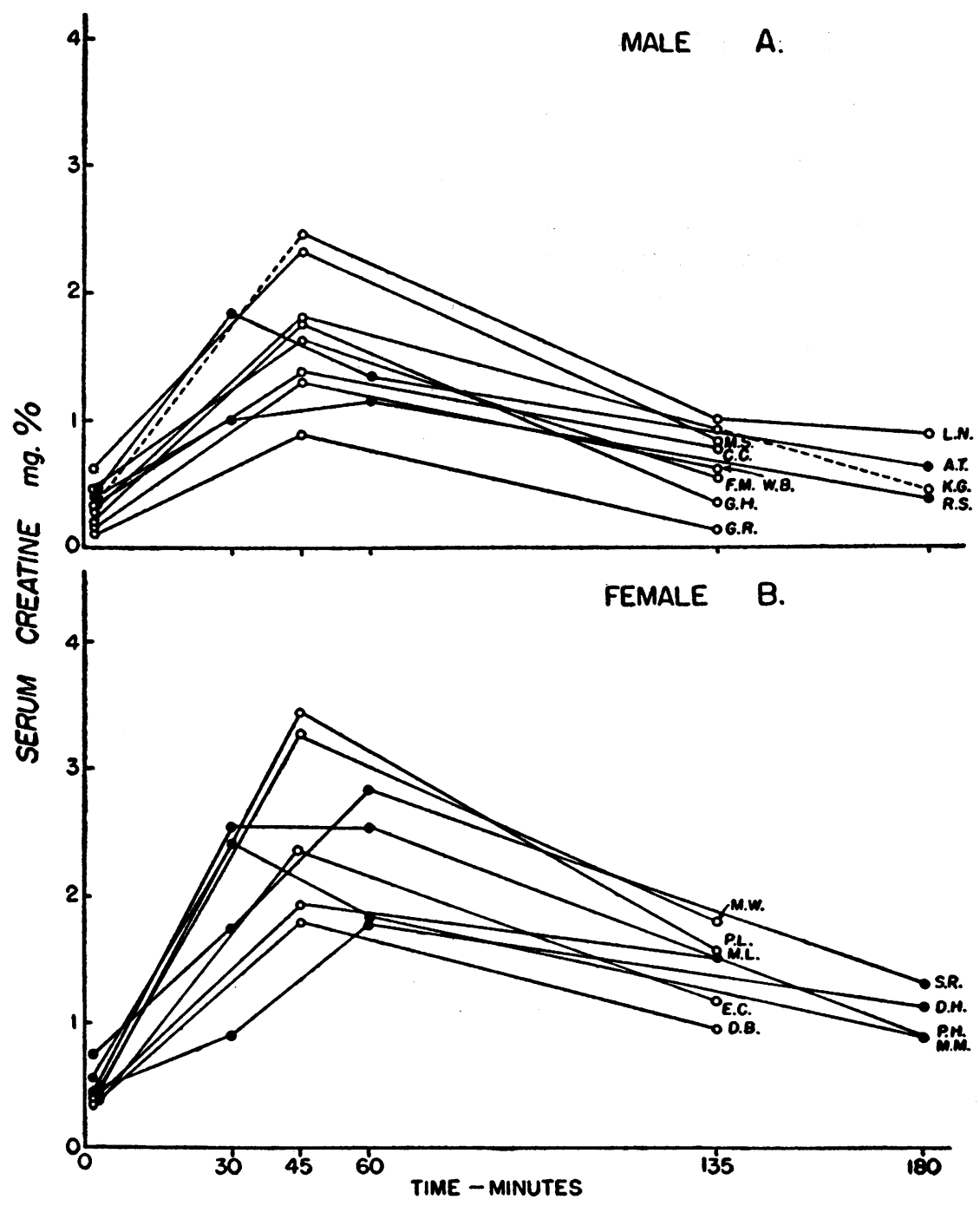

Fig. 1. Normal Adults

Open circles represent authors' cases, solid circles from Tierney and Peters (6). $A$. Males. In two cases, points connected to curves by a broken line were determined on a separate occasion, in one instance because of a laboratory accident, in the other because the 135 minute value was suspiciously high. B. Females. Comparison of the male and female groups at 135 minutes, using the " $t$ " test, reveals a " $p$ " value of 0.001 , indicating that the sex difference is a real one. No such difference is demonstrable at 30,45 , or 60 minutes. The highest male fasting concentration is 0.60 , approximately the "threshold" level for creatinuria. 


\section{Effects of treatment}

Figure $3 \mathrm{~A}$ demonstrates the prompt return of all but one of the tolerance curves to the normal area early in the course of medical treatment. Thus one case treated with Lugol's solution, seven with propyl thiouracil and two who received both drugs all display normal male patterns. Females, on the other hand (Figure 3B), have been shown to respond less completely when given Lugol's solution.

The curves in Figure 4A, representing later stages in the course of preoperative preparation, or of medical therapy in unoperated cases, indicate that the correction of the defect in creatine

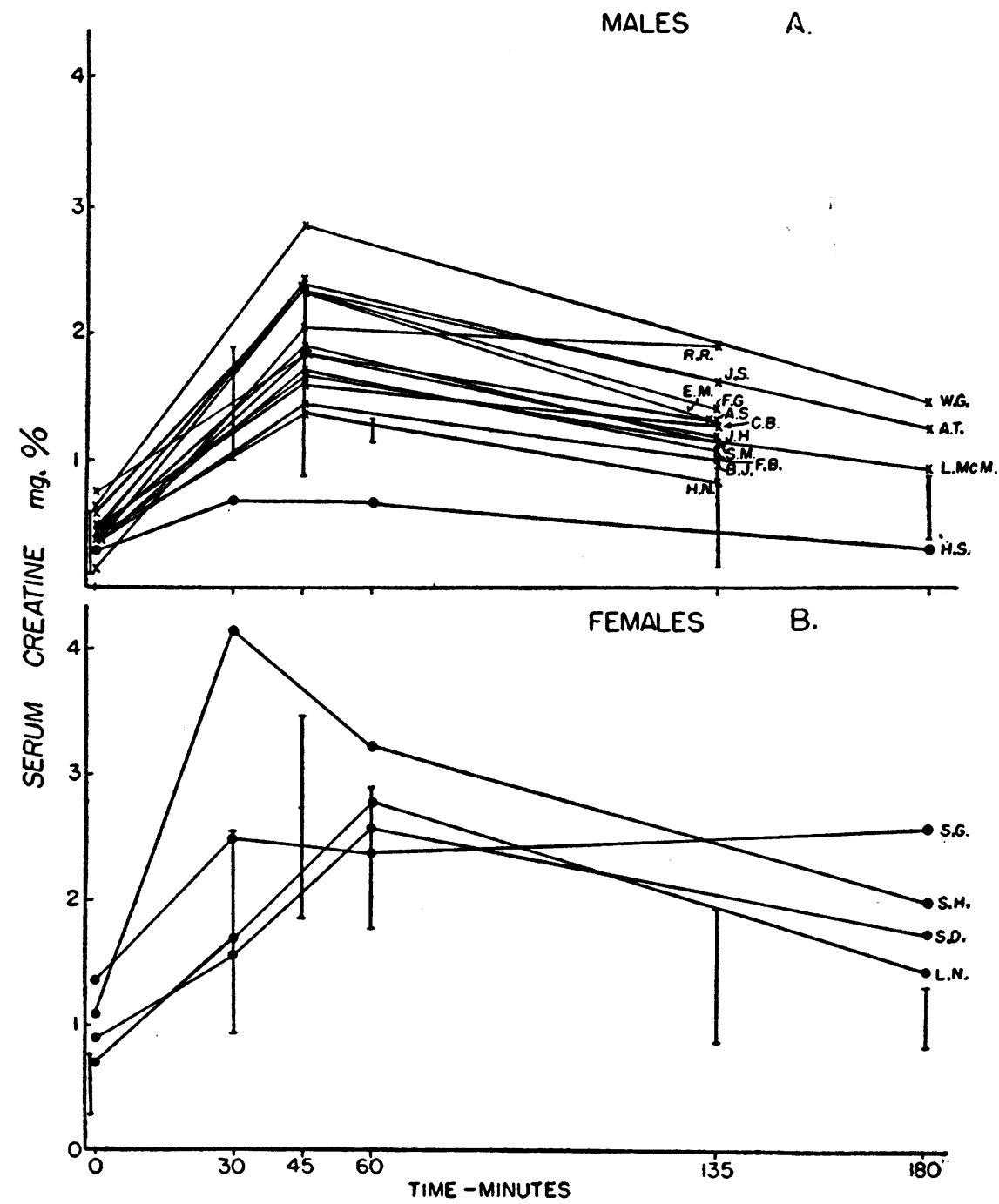

Fig. 2. UNTREATED HYPERTH YROIDISM

Vertical bars represent normal ranges from Figure 1. Crosses $(X)$ authors' cases. Circles ( $\bullet$ from Tierney and Peters (6). A. Males, B. Females. Comparison of the male normal and hyperthyroid group at 135 minutes indicates a very real difference in that application of the " $t$ " test reveals a " $p$ " value of 0.0001 . At 180 minutes the difference is similarly real, the fact that " $\mathrm{p}$ " is 0.01 being attributable to the small number of cases (in this instance the case of Tierney and Peters represented by the solid circle was omitted from the analysis, perhaps unjustifiably). The difference in the female groups at $\mathbf{1 8 0}$ minutes is also real. In neither males nor females can significance be attached to the fasting, 30,45 , or 60 minute values. 
metabolism suggested by Figure $3 \mathrm{~A}$ is not persistent in all cases, since the final creatine values for both F. B. and L. McM. are higher than in Figure $3 \mathrm{~A}$ and somewhat exceed the normal range after 30 and 31 days of therapy, respectively. The one patient showing a definitely abnormal pattern after 13 and 31 days' medication (B. J.-Table II) had received Lugol's solution for a prolonged period prior to hospital admission, and treatment with propyl thiouracil was started 25 days later.

Following thyroidectomy, all of the patterns become normal, even those checked as early as seven days after operation (Figure 4B).

\section{Other disorders}

Eleven studies performed in four cases with nontoxic adenomas of the thyroid, one suspected of thyroiditis, one suspected of hyperfunction of the gland following a previous thyroidectomy, one suspected of hyperthyroidism and subsequently found to have a malignant sarcoma, and one outpatient with neurosis suggestive of thyroid disease, are reproduced in Figure 5. Clinical data are given in Table III. Unfortunately, the diagnostic specificity of the tolerance technique is impugned by the fact that the curve of the most complex

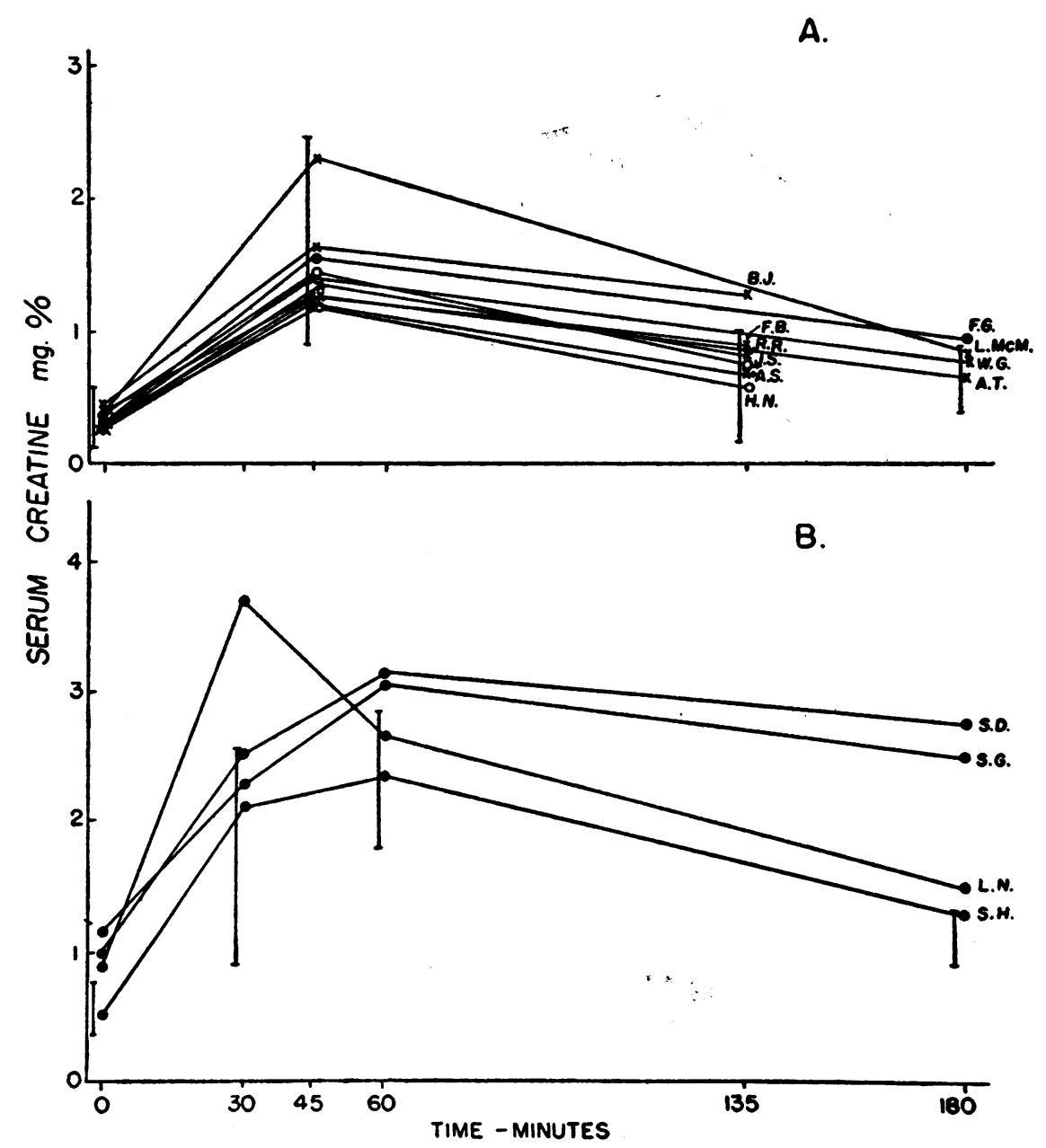

Fig. 3. Early Therapy

Vertical lines represent normal range from Figure 1. Solid circles $(\bullet)$ indicate treatment with Lugol's solution, crosses $(X)$ propyl thiouracil and open circles $(O)$ therapy with both drugs. A. Males after ten days of medical treatment. B. Females after Lugol's solution, duration not stated, from Tierney and Peters (6). 


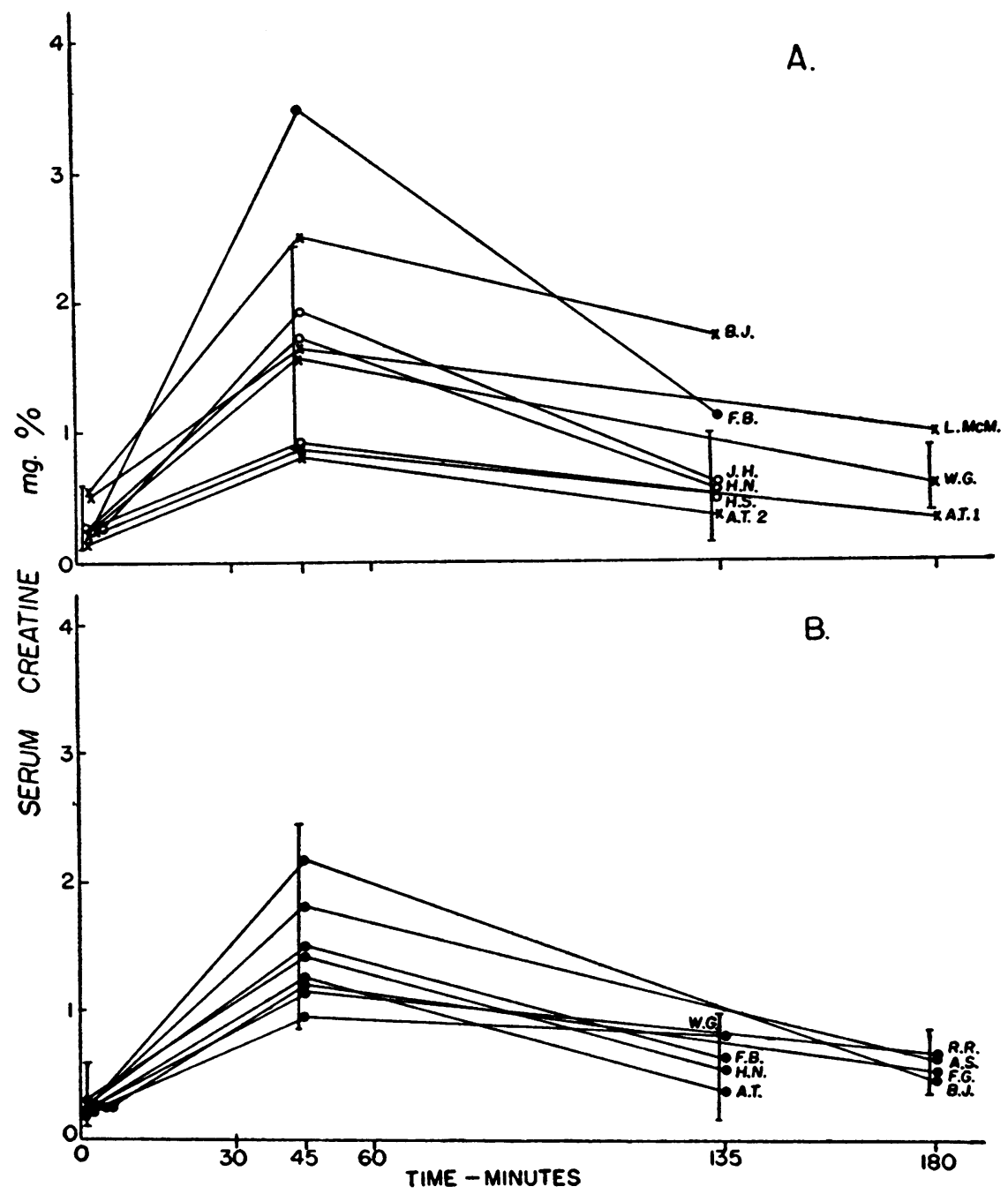

FIG. 4.

Vertical bars represent normal range from Figure 1. A. Later medical therapy and preoperative case (symbols as in Figure 3A). B. Postoperative cases.

clinical problem (H. W.-Table III) was equivocal while the serum iodine and basal metabolism were in agreement. The abnormal pattern in the second study on $\mathrm{H}$. C. can legitimately be assigned to physical deterioration associated with progression of his malignancy.

\section{Serum creatinine values}

Despite the dramatic alterations in serum creatine pattern during treatment of these cases, the creatinine remained relatively constant throughout. The range of values encountered, $0.77-$
$1.62 \mathrm{mg} . \%$ (excepting values in the sarcoma patient in his terminal illness, H. C.-Table III) are in keeping with those previously reported in normals with this method $(5,6,14)$. The maximum variation observed in any single tolerance was $\pm 0.36 \mathrm{mg}$. $\%$, while in all but three cases the variation was $\pm 0.16 \mathrm{mg}$. \% or less. Furthermore, there was probably no significant trend after treatment or operation, although four patients, A. S., W. G., R. R., and H. N., showed an increase of $0.22 \mathrm{mg}$. \% or more in postoperative fasting creatinine over pretreatment levels, and only 


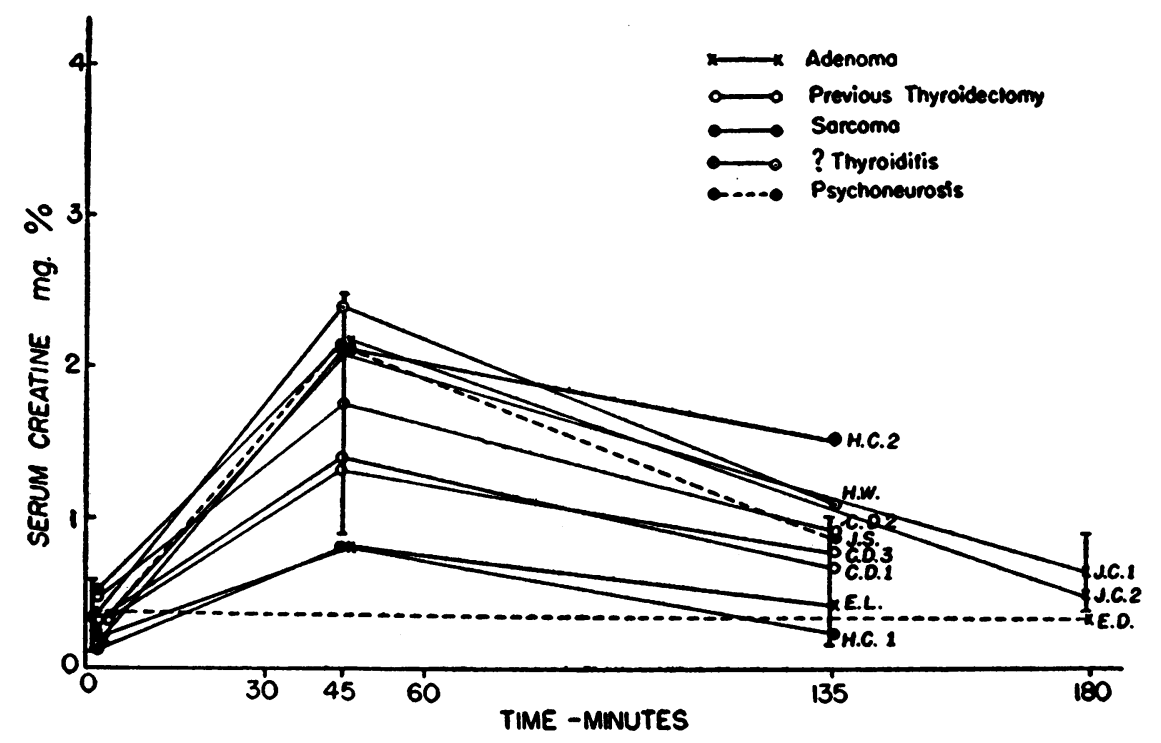

Fig. 5. Non-Toxic Thyroid Diseases

Vertical lines represent normal range from Figure 1. Broken line (E. D.) indicates that the $\mathbf{4 5}$ minute specimen was technically unsatisfactory.

one patient, F. G., showed a significant decrease $(0.13 \mathrm{mg}$. \%). The constancy of creatinine in this regard has been noted by others $(6,15)$.

\section{DISCUSSION}

Examination of the overlap in values for males and females, normal or hyperthyroid, at the 30,45 , and 60 minute points in Figures 1 and 2 demonstrates that the alterations in creatine concentration at these intervals are of little or no diagnostic significance. Attention should, however, be drawn to the fact that in males serum concentrations, in this series (Figures 1-5) and in others (16), virtually never exceed $3.0 \mathrm{mg}$. \%. In interpreting tolerance patterns the final (135 or 180 minute) specimen offers the most information and is the one which we have utilized in the interpretation of our findings. In fact, the data presented suggest that omission of the intermediate tolerance points is probably justified for practical purposes.

Females predominate in most reported case series of hyperthyroidism, and little information is available regarding creatine tolerance in males with this disease. The information obtained from the present study strongly suggests that the creatine disturbance in males is similar qualitatively but not quantitatively to that seen in women. In Graves' disease the male curves tend to become fe- male, while female curves develop "super-feminine" characteristics, i.e., an exaggeration of their normally-present inability to retain exogenous creatine in body depots. That this does not represent a complete blockage of creatine deposition and creatine-creatinine conversion in either sex has repeatedly been confirmed by measurements demonstrating that only a fraction of the administered creatine is wasted in the urine, usually less than $50 \%$, even in the case of female hyperthyroid patients $(2,4,6)$.

The fact that these shifts are approximately equal both directionally and quantitatively since the ranges of the 135 and 180 minute values for normal females correspond almost exactly to those for the hyperthyroid males (Figures $1 B$ and $2 A$, respectively), suggests a cancellation of the anticreatinuric effects of male androgenic secretion by the creatinuric action of excessive thyroid activity in this situation. Nevertheless, the mere fact that these antagonistic effects approximate one another in magnitude obviously fails to either confirm or deny existing concepts of thyroid-gonad interrelationships.

Creatine tolerance tests have been declared unsuited for use in the diagnosis of thyrotoxicosis (13), and so has measurement of endogenous creatinuria $(17,18)$. This is certainly true of en- 
dogenous creatinuria in females. Normal women excrete creatine unpredictably but frequently, so that evaluation of its significance in individual instances is often impossible (6). In our relatively small number of cases the serum tolerance pattern in men has proved to be more specific, although the group is too small to exclude the possible existence of other types or stages of the disease in which normal curves might be found. Similarly, it is possible that the creatinuric "non-thyrotoxic hypertensives" reported by others (17) may display comparably reduced tolerances. To date, it has not proved possible for us to investigate the responses of such individuals.

Although in the few cases examined the creatine tolerance proved to be a valid index of thyroid function about as frequently as did the metabolic rate or the serum iodine, the number of patients is too small to justify such comparison at this time. However, it seems permissible to state that although determination of serum precipitable iodine and of basal metabolic rate are doubtless the most valuable procedures currently available for the diagnosis of abnormal function, the serum creatine tolerance is far more economical than the former, and proved to be a valid index in at least 19 of the 22 cases reported in this series. In instances where serum iodine data may be misleading (7-9) or where determination of the basal metabolic rate is technically impractical, the tolerance procedure may be of considerable clinical assistance in patients of either sex provided that the observer recognizes that such complicating conditions as cachexia, cardiac decompensation and acute infection may cause fundamental, and potentially confusing, disturbances of creatine metabolism. Furthermore, in certain respects the serum tolerance is preferable to the determination of postingestion creatinuria. Incomplete emptying of the bladder or the necessity of using catheters may be an obstacle to urinary studies. Preliminary investigations also suggest that serum tolerances may furnish more exact information in the differential diagnosis of other metabolic disorders (19).

As reflected in the creatine metabolism, response to therapy is prompt, and in most cases complete. The apparent failure of two patients to maintain the early improvement of creatine tolerance after moderately prolonged medical ther- apy (F. B. and L. McM.-Figure 4A), and the limited response of a third (B. J.), who had had a prolonged course of Lugol's solution prior to hospitalization, are singularly reminiscent of the once-popular concept of "iodine escape." It would however, obviously be improper to attach significance to changes which are quantitatively so small. Comparison with response to therapy in females (Figure 3B) is not justified since no data are available regarding the clinical or metabolic status of the female series. The evidence suggests that the female response is less complete or less prompt. On the other hand, it may have merely been less permanent, a possibility suggested by the data depicted in Figure 4A.

On comparing the effects of therapy depicted in Figure $3 \mathrm{~A}$ with the clinical and laboratory findings in Table II, one finds that in most instances the basal metabolism and pulse rate were still elevated, although creatine tolerances were improved. It would be unwise, in view of our ignorance of the mechanisms involved, to attempt a physiologic interpretation of this fact. However, clinical experience furnishes a comparable phenomenon in that hyperthyroid patients frequently admit to subjective improvement during the early days of therapy before objective changes are detectable. Others have related the abnormalities in creatine metabolism in Graves' disease to the myasthenia seen in these patients $(3,4)$, and it seems logical to propose that the increased well-being reported by these individuals may be an expression of this early return of the ability to deposit creatine in the normal manner.

Patients with hypothyroid states (16) have failed to reveal as clear-cut a pattern as that observed in this study, and further data must be collected before definitive material can be reported. The tolerance patterns in hypermetabolic leukemia are inconstant, and often bizarre. Preliminary data suggest that the aberrations noted are not the result of impaired renal function or of uric acid chromogenicity (20). Further investigations are in progress.

\section{SUM MARY AND CONCLUSIONS}

1. Serum creatine tolerance curves (1 gm. p.o.) offer a more reliable index of thyroid function in males than in females. 
2. There is in most instances a prompt improvement in tolerance to or toward normal patterns early in the course of medical therapy.

3. Creatine tolerances promptly reverted to the normal pattern in all instances following thyroidectomy.

4. The procedure confirmed clinical opinions and other laboratory findings in 12 of 13 cases of hyperthyroidism as well as in seven out of eight cases of suspected or non-toxic thyroid disease. In one instance, the diagnosis remains in doubt, but the tolerance was probably not in agreement.

5. Serum creatinine levels are essentially normal in male hyperthyroidism, tend to rise following thyroidectomy, and do not fluctuate significantly $\left(<0.4 \mathrm{mg}\right.$. \%) during the course of a $2 \frac{1}{4}$ or three hour test.

\section{ACKNOWLEDGMENTS}

The authors wish to express their appreciation to Mr. Joseph D. Teller and to Mrs. Elva C. Ketchman for processing blood samples and to Mrs. Suzanne J. Huff for her supervision of the serum iodine and thyroxine determinations.

Mr. Carrol Weil performed the statistical analyses.

\section{REFERENCES}

1. Palmer, W. W., Carson, D. A., and Sloan, L. W., The influence of iodine on the excretion of creatine in exophthalmic goiter. J. Clin. Invest., 1929, 6, 597.

2. Richardson, H. B., The relation of the thyroid gland to Graves' disease. M. Clin. N. America., 1934, 18, 791.

3. Richardson, H. B., and Shorr, E., The creatin metabolism in atypical Graves' disease. Tr. A. Am. Physicians, 1935, 50, 156.

4. Thorn, G. W., Creatine studies in thyroid disorders. Endocrinology, 1936, 20, 628.
5. Peters, J. H., The determination of creatinine and creatine in blood and urine with the photoelectric colorimeter. J. Biol. Chem., 1942, 146, 179.

6. Tierney, N. A., and Peters, J. P., The mode of excretion of creatine and creatine metabolism in thyroid disease. J. Clin. Invest., 1943, 22, 595.

7. Peters, J. P., and Man, E. B., The relation of albumin to precipitable iodine of serum. J. Clin. Invest., 1948, 27, 397.

8. Danowski, T. S., Johnston, S. Y., and Greenman, J. H., Alterations in serum iodine fractions induced by the administration of inorganic iodide in massive dosage. J. Clin. Endocrinol., 1950, 10, 519.

9. Man, E. B., and Peters, J. P., Artifactual values of serum precipitable iodine. J. Lab. \& Clin. Med., 1950, 35, 280.

10. Danowski, T. S., Huff, S. J., Garver, K., Wirth, P., and Peters, J. H., Unpublished studies.

11. Peters, J. H., Unpublished data.

12. Grossman, C. M., The effect of amino acids on serum and urine creatine. J. Clin. Invest., 1945, 24, 380.

13. Sohval, A. R., King, F. H., and Reiner, M., The creatine tolerance test in the differential diagnosis of Graves' disease and allied conditions. Am. J. M. Sc., 1938, 195, 608.

14. Samuels, L. T., Sellers, D. M., and McCauley, C. J., The source of excess creatine following methyl testosterone. J. Clin. Endocrinol., 1946, 6, 655.

15. Lundbaek, K., Investigation of some biochemical changes occurring during treatment of hyperthyroidism. Acta. med. Scandinav., 1947, 127, 193.

16. Peters, J. H., Mateer, F. M., Mermelstein, H., Schwartz, R., Mansuy, M. M., and Yoder, R. D., Unpublished studies.

17. Treusch, J. V., Kepler, E. J., Power, M. H., and Haines, S. F., Creatinuria in hyperthyroidism and in essential hypertension. Am. J. M. Sc., 1944, 208, 310.

18. Wang, E., Clinical and Experimental Investigations on the Creatine Metabolism. Mercators Tryckeri, Helsingfors, 1939.

19. Snyderman, R., Peters, J. H., Nefores, M. N., and Mermelstein, H., Unpublished studies.

20. Mansuy, M. M., Peters, J. H., Nefores, M. N., Huff, S. J., and Danowski, T. S., Unpublished studies. 